過呼吸負荷時における心電図R-R間隔の变動

一青年者と高齢者の比較一

岩月宏泰1

$\mathrm{R}-\mathrm{R}$ intervals during deep breathing --comparison between old and young subjects-Hiroyasu IWATSUK I, RPT ${ }^{1}$ ' .

1) Depertment of Physical Therapy, Nagoya University, College of Medical Technology

1-1-2 Daikouminami Higashi-ku Nagoya 461 Japan. TEL 052-723-1111.

J.Exerc. Physiol. 6(4):187-191,1991. Sibmitted Jan. 28,1991. Accepted June.20,1991. ABSTRACT

In order to examine how physiological aging affects the function of autonomic nervous system, we recorded $R-R$ intervals of 25 healthy females (aged 20-79) under the condition of deep breathing (12 times/min). 0ld subjects showed significantly lower SD, CV, MV ratio, and MV rate than young subjects throughout experiment. Increasing rates of $\mathrm{CV}$ during deep breathing were $6.4 \%$ and $27.6 \%$, respectively. Both old and young subjects indicated $25 \%$ increase in HR max-min during hyperventilation.

0ld subjects showed vagotonia of heart even during deep breathing, which suggests that 3 -minute deep breathing induces smaller depth of each breath.

Key words: old subject, deep breathing exercise, R-R interval, female

要旨

健常女性25名（20-79歳）を対象に過呼吸負荷（1 分間に12回の深呼吸）した際の心電図 のR-R 間隔変動を指標として自律神経機能における生理的加舲の影響について検索した。安静 時、過呼吸中おょび終了後とも高齢者は青年者より S D , C V、MV ratio、MV rate の各指標 で有意な低值を示した。過呼吸中の C V 増加率は青年者が $6.4 \%$ であり、高齢者が $27.6 \%$ あ った。また、過呼吸中のHR max-min は青年者、老年者とも約 $25 \%$ の増加を認めた。

高齢者では過呼吸中でも心迷走神経活動の充進を認めたことから、3 分間の過呼吸を維持す るために呼吸深度が浅くなったことが示唆された。

\title{
キ-ワード: 高齢者、過呼吸負荷、心電図R-R間隔、女性
}

1) 名古屋大学医療技術短期大学部理学療法学科:名古屋市東区大幸南1-1-20 ( 1461 )

TEL $052-723-1111$

運動生理6(4): 187-191,1991。受付日 1991年1月28日受理日1991年6月20日 
I 緒 言

安静時でも心拍動が自発的、律動的な変動 を示すことが従来から知られていた。特に心 拍数は吸息相に頻脈、呼息相に徐脈と呼吸運 動に同期して周期的に変化する。この呼吸に よる不整脈はアトロピンで抑制されること ${ }^{11}$ 吸息相の頻脈が心胹迷走神経活動の抑制と同 期していること泉 から、呼吸性不整脈は副交 感神経機能を反映する指想となり得ると考え られている。現在では呼吸性不整脈を心電図 の $\mathrm{R}-\mathrm{R}$ 間隔変動から定量的に捉える方法が多 く用いられている。

心電図のR-R間隔変動の算出方法として、影 山ら)の提唱した変動係数 (CV) が広く普 及しているが、R-R変動幅と平均心拍数は直線 関係でなく、二次の関数関係にあること 4 , 5) などから、 C Vより標準偏差（S D ）の方が 感度が高いことが指摘されている61。そのた め心電図R-R間隔の变動を検討する際には、C Vだけでなく他の指標も考える必要があると 考えられる。

一方、自律神経機能は生理的加柃により著 しい影響を受けることが知られているが、そ の機能低下は性差がないという報告7.8) と女 性には加齢による変化が軽微であるという報 告9.10) がある。本研究では健常女性における 自律神経機能の生理的加㱓の影響を過呼吸負 荷した際の心電図のR-R 間隔変動から検索し た。

\section{II 対 象}

対象は健常女性 25名（年齢 20-79歳）で、

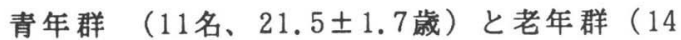
名、72.0 0 8.1歳）の 2 群に分けた。被験者は 心・肺疾患を有する者、糖尿病患者、降圧剂、 抗コリン剂の服用者およびアルコール、喫煙 の習慣のある者を除外した。
III 方 法

方法は食後 2 時間以上経過した被験者に安 静仰臥位をとらせ脈拍が安定した後に日本光 電製（ECG 8250）心電計を用いて四肢誘導で 心電波形を記録した。心電図は普通呼吸によ る安静時、検查者の掛け声に合わせて 1 分当 り 12 回（吸入 2.5 秒、呼出 2.5 秒）の深呼吸を 3 分間負荷させ、過呼吸中と終了直後を測定 した。心電波形は心電計に内蔵されたマイク ロコンピューターにより、連続する100拍の $R-R$ 間隔について算出した。解析には普通呼吸 時および過呼吸時における $R-R$ 間隔の平均值

(MEAN)、標準偏差 ( S D ) 、最大值 (MAX) 最小值（MIN）、変動係数（CV)、最大変動 比（MV ratio）、最大変動率（MV rate）の各 指標および最大心拍数と最小心拍数の差（HR max-min) を求めた（Table 1)。

Table 1. Abbreviations of indices for $R-R$ interval variation

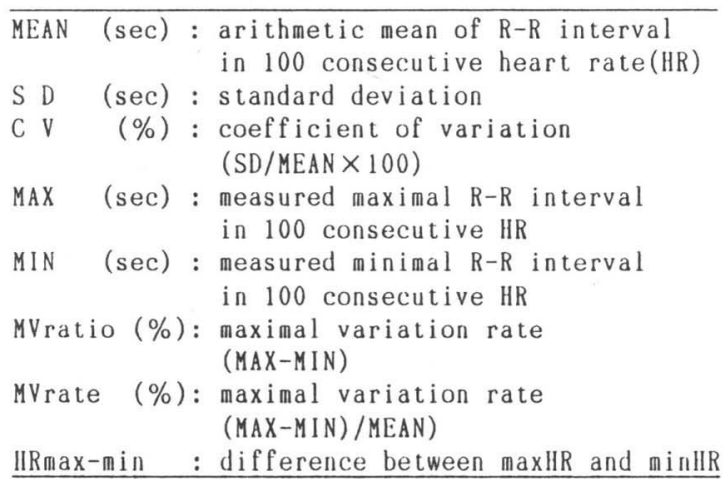

III 結 果

Table 2 に過呼吸負荷前後の心電図のR-R間 隔変動の各指標を示した。安静時、過呼吸中、 終了後の全ての測定条件でR-R間隔のMEAN、 MAX、MINに年齢による差を認めなかったが、 老年群のS D、C V、MV ratio、MV rateは青 
Table 2. Comparison of indices for $R-R$ interval variation between young and aged subjects

\begin{tabular}{|c|c|c|c|c|c|c|c|}
\hline & \multicolumn{2}{|c|}{ Before } & \multicolumn{2}{|c|}{ During H.V. } & \multicolumn{2}{|c|}{ After } \\
\hline & & YOUNG & AGED & YOUNG & AGED & YOUNG & AGED \\
\hline MEAN & (sec) & $0.93 \pm 0.09$ & $0.92 \pm 0.14$ & $0.80 \pm 0.08$ & $0.88 \pm 0.16$ & $0.94 \pm 0.09$ & $0.92 \pm 0.15$ \\
\hline S D & (sec) & $0.05 \pm 0.01$ & $0.02 \pm 0.01$ & $0.05 \pm 0.02$ & $0.03 \pm 0.01$ & 0.02 & $0.02 \pm 0.01$ \\
\hline C V & (sec) & $5.28 \pm 1.84$ & $2.50 \pm 1.23 * *$ & $5.62 \pm 2.02$ & $3.02 \pm 1.18 * *$ & $6.65 \pm 2.08$ & $2.28 \pm 0.99 * *$ \\
\hline & $(\mathrm{sec})$ & $1.02 \pm 0.11$ & $0.97 \pm 0.15$ & $0.92 \pm 0.11$ & $0.94 \pm 0.17$ & $1.06 \pm 0.11$ & $0.97 \pm 0.17$ \\
\hline & $(\mathrm{sec})$ & $0.81 \pm 0.07$ & $0.86 \pm 0.13$ & $0.70 \pm 0.06$ & $0.82 \pm 0.15$ & $0.77 \pm 0.10$ & $0.87 \pm 0.14$ \\
\hline MV ra & $\operatorname{tio}(\%)$ & $1.26 \pm 0.08$ & $2.50 \pm 1.23 *$ & $1.30 \pm 0.15$ & $1.15 \pm 0.06 *$ & $1.39 \pm 0.16$ & $1.11 \pm 0.05 * *$ \\
\hline MV ra & $(\%)$ & $0.23 \pm 0.07$ & $0.12 \pm 0.05 * *$ & $0.26 \pm 0.12$ & $0.14 \pm 0.05 *$ & $0.31 \pm 0.10$ & $0.11 \pm 0.04 * *$ \\
\hline
\end{tabular}
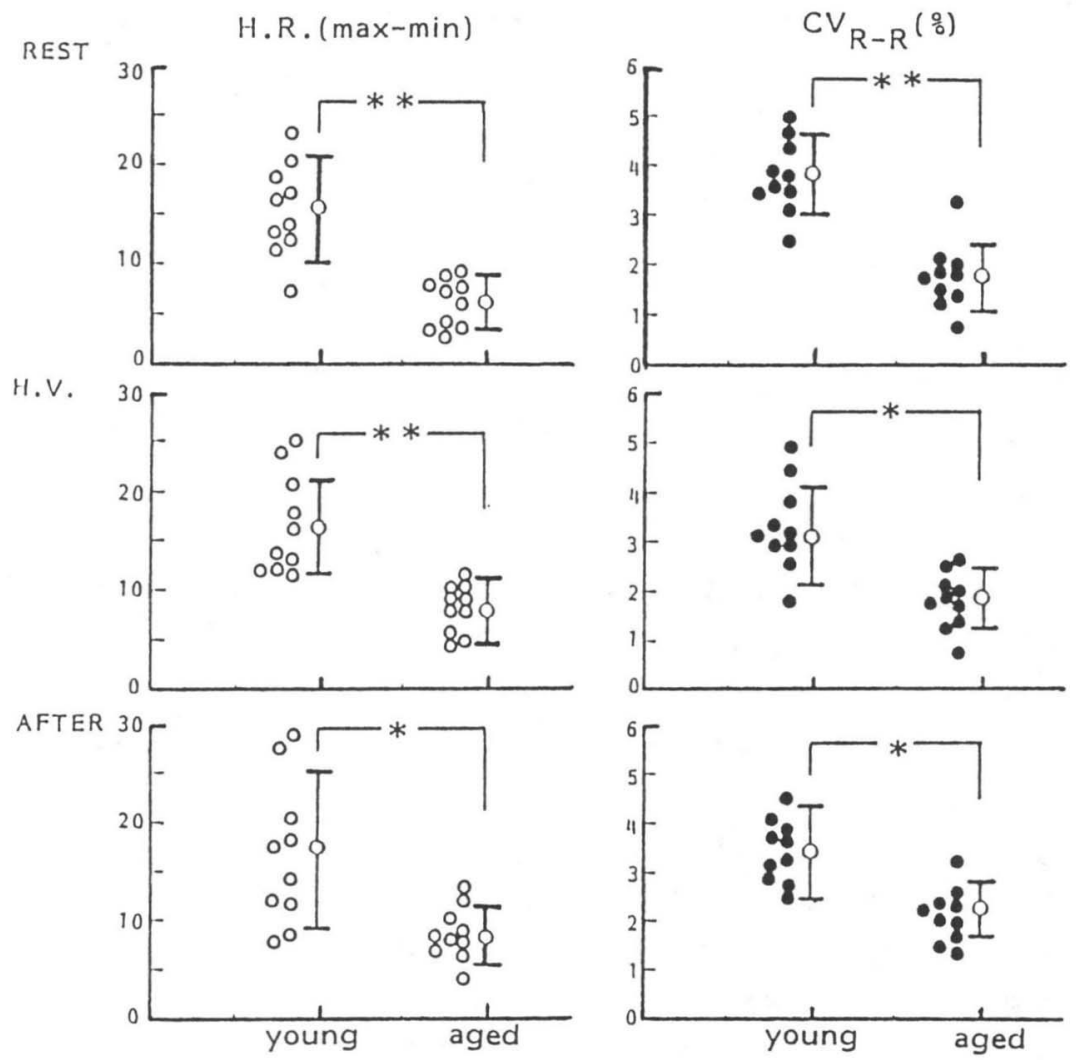

$* *: \mathrm{p}<0.01, *: \mathrm{p}<0.05$

Fig.1. Comparison of $\mathrm{CV}_{R-R}$ and $\mathrm{HRmax}-$ nin between young and aged subjects H.V.; during hyperventilation 
年群より有意な低値を示した（各々 $\mathrm{p}<0.05$, 0.01）。またFig.1に示したが安静時のC V は 青年群 $5.28 \pm 1.84 \%$ 、老年群 $2.50 \pm 1.23 \%$ と 老年群が有意に低かった（ $\mathrm{p}<0.01 ） 。$

また両群の C V とも安静時に比べて、深呼吸 中、終了後の値と有意な差を認めなかった。 しかし、老年群の C V は過呼吸中 $27.6 \%$ 増加 し、青年群は終了後に $25.9 \%$ の増加を示した。 各測定条件におけるHR max-minは安静時の青 年群 $15.63 \pm 5.47$ 、老年群7.78 3 3.66であり、 老年群が有意な低值を示した $(p<0.01)$ 。深 呼吸中、終了後においても老年群は青年群よ り有意な低値を示した $(p<0.01)$ 。梁呼吸中 ではHR max-min両群とも安静時より約 $25 \%$ 前 後の増加を示し、終了後では青年群 $41.8 \%$ 、 老年群 $6.7 \%$ の增加を認めた。

\section{IV 考 察}

心電図のR-R 間隔変動による心副交感神経 機能の検査は定量的で再現性のある方法とし て、自律神経障害を伴う糖尿病および中枢神 経疾患に応用されている。

また心電図の $\mathrm{R}-\mathrm{R}$ 間隔変動の測定条件とし $\tau$ 、安静臥床時、深呼吸時、Valsalva負荷、 体位変換などがあり、表現法についても種々 の報告がある。景山ら ${ }^{3)}$ が有用性を提唱した 心電図 $\mathrm{R}-\mathrm{R}$ 間隔の $\mathrm{C} V$ は検出機器の普及が早 かったため、本邦で用いられることの多い指 標である。しかし、C V は前述した問題を含 んでおり、S D も心拍数との関連が強く、值 が頻脈時に小さく、徐脈時に大きく示される ことから、心拍変動の指標として何を用いる かは議論の多いところである。及川 ${ }^{11}{ }^{\prime}$ は安静 仰臥位で基整心拍数が安定している時には C V、S D が、心拍変動の中心が移動する場合 には $\mathrm{R}-\mathrm{R}$ 間隔の 2 乗の平均値を用いることの 正当性を説明している。森寺ら ${ }^{12)}$ は安静仰臥 位ではCVが、種々の負荷を加えた際にはHR max-minが最も感度が高いと考えている。

本研究では心電図のR-R 間隔変動の指罡と して、MEAN、S D、MAX、MIN、C V、MV ratio MV rateおょびHR max-minから検討した。MEAN MAXおよびMINを除く他の指標は安静時、過呼 吸中、終了後の全ての条件でも老年群が青年 群より有意な低値を示した。

自律神経機能の加齢の影響を検討した報告 では副交感神経機能は加路に伴い低下し、血 圧を介する交感神経反射は加齢の影響を受け ないと述べているものが多い13.15)。しかし、 田村ら ${ }^{19) ~}$ は高齢者の交感神経機能において 安静時活動性が妄進しているが、刺激時の反 応性が鈍化してると推測している。副交感神 経機能の指樌と考えられている C V は性差が なく、高齢者になるにつれて低下するという 報告が多い3,7,8,14)。本研究でも高齡者のC $\mathrm{V}$ は青年者に比べ有意に低下していた。

また過呼吸負荷では青年群、老年群の C V は增加する傾向がみられた。過呼吸負荷中は 頻脈となるが、これは $\mathrm{PCO}$ を低下させること で呼吸中枢の抑制が促通され、交感神経活動 の六進と迷走神経活動の低下の結果で生じた と考えられる。このため、 C V は安静時より 低值を示すと考えたが、青年群が $6.4 \%$ 、老年 群が $27.6 \%$ と高歯者で增加する傾向を認めた。 過呼吸は被験者の協力を必要とするため、 呼吸樑度、分時呼吸回数によって心拍数が影 響される。本研究では分時呼吸数 12 回の梁呼 吸を負荷させたが、両群とも頻脈となり C V も増加した。またHR max-minも両群とも過呼 吸負荷時に約 $25 \%$ 前後の増加を認めた。これ らのことから、深呼吸は副交感神経機能を高 める負荷となっていることが考えられる。つ まり、梁呼吸は呼吸性不整脈の発生因子15) と いわれている肺、胸郭内の伸張受容器を介す る反射、呼吸中枢から心血管中枢へ伝達する 中枢性因子、および大動脈圧受容体を介する 反射の何れかを高めていることが推測され得 る。しかし、高齢者では副交感神経系の指铎 
となる C V が深呼吸中で増加したことから、 心迷走神経活動が立進したと考えられる。こ の理由として過呼吸は被験者の努力に依存す るため、高齢者では設定された呼吸回数を約 3 分間継続するために呼吸梁度が低くなった ことが推測され得る。

心拍変動を指標とした自律神経機能検查に は種々の測定法があるが、測定時には本研究 で明らかのように加齢、呼吸方法、日内変動 など測定值を変動させる因子を考虑して行う ことが重要であると考えられる。

\section{参考文 献}

1) Pfeifer,M.A. et al.:Quantitative evaluation of cardiac parasymathetic activity in normal and diabetic man. Di abe tes , $31: 339,1982$.

2)Coker,R. et al.: Does the sympathetic nervous system influence sinus arrhythmia in man? Evidence from combined au tonomic blockade. J. Physiol. ,356:459, 1984.

4)Katona,P.G. \& Jih,F.: Respiratory sinus arrhythmia; noninvasive measure of parasympathetic cardiac control.

J. Appl. Physiol.,39:801,1975.

5)Murray, A., et al.:R-R interval variation in young male diabetics. Brit. Med. J. , $37: 882,1975$.

6)鈴木吉彦、他: 糖尿病性神経障害一自律神 経異常一。臨床脳波, 32:23,1990.
7) 藤田博暁・他: 高齢者における心電図 $R-R$ 間隔 の分析. 理学療法学, $16: 29,1989$.

8)Kuroiwa, Y. ,et al. : Measurement of blood pressure and heart-rate variation while resting supine and standing for the evaluation of autonomic dysfunction.

J. Neurol. ,235:65,1987.

9) Vita,G. et al.: Cardiovasucular reflex tests-Assessment of age adjusted normal range. J. Neurol. Sci. 75: 263, 1986.

10)田村直俊·他: 心 - 血管系自律神経反射の加 齿変化および性差について. 自律神経, 2 : $498,1989$.

11) 及川 登・他: 心拍数変動を用いた糖尿病性 自律神経障害の定量的評価（第一報）

一自律神経障害判定のための基準值の設定 糖尿病, $26: 1123,1983$.

12) 森寺邦三郎・他: 糖尿病性自律神経障害一 心電図 $R-R$ 間隔の変動による検討一. 自律神 経 $21: 1,1984$.

13) 北澄忠雄・他: 自律神経性循環調節に及ほす 加齢と高血圧の影響. 日老医誌 $2: 1$, 1985.

14) 黒岩義之: 心電図 $R-R$ 間隔変動測定. 臨床脳 波,31: 771,1989.

15）佐藤磐男・他: Heart Periodの律動的変動 の意義と臨床応用. 呼と循, $28: 964,1980$.

16) 相原一夫・他: 心電図 $R-R$ 間隔の日内変動と 再現性. 神経内科, $22: 476,1985$.

17) Ewing, D. J. ,et al. : Assessment of methods for estimating autonomic nervous control of the heart in patients with diabetes mellitus. Diabetes, 27:1167, 1978. 